\title{
THE POSSIBILITY OF MUTUAL CONTROL OF STEM MINING WEEVILS AND POLLEN BEETLE IN OILSEED RAPE
}

\author{
JURAN I. * GRUBIŠIĆ, D. - OKRUGIĆ, V. - GOTLIN ČULJAK T. \\ University of Zagreb Faculty of Agriculture, Svetošimunska 25, 10000 Zagreb, Croatia \\ (phone: +385-1-239-3737) \\ *Corresponding author \\ e-mail: ijuran@agr.hr; phone: +385-1-239-3965 \\ (Received 21 $1^{\text {st }}$ Feb 2020; accepted 25 $5^{\text {th }}$ May 2020)
}

\begin{abstract}
Stem weevils and pollen beetle are significant pests that attack oilseed rape crops after winter hibernation. Correct timing of insecticide application is a key point in control of both pests. The aim of this research is whether the mutual control of both pests is possible in order to reduce insecticide input. The two-years experiment was set up according to the EPPO guidelines in random block design in four replications with nine different treatments. The optimal treatment period was determined by monitoring the occurrence and population density of stem weevils using yellow water traps. The decision threshold for pollen beetles was determined by beating terminal inflorescences into trays. The use of insecticides against rape stem weevils and pollen beetles is possible if thresholds are exceeded at the same time. All insecticides applied against stem mining weevils increased rapeseed yield, and in the absence of treatment, the average loss of oilseed rape seed yield was $37 \%$.
\end{abstract}

Keywords: oilseed rape, pests, integrated pest management, Curculionidae, Nitidulidae

\section{Introduction}

Oilseed rape stem weevil (Ceutorhynchus napi Gyllenhal, 1837) and cabbage stem weevil (Ceutorhynchus pallidactylus Marsham, 1802) (Coleoptera: Curculionidae) are the first pests which attack oilseed rape plants after winter hibernation. They are often considered as a pest complex due to their biological and ecological characteristics which are similar although their life cycles are different and demand different control approach. Pollen beetle (Brassicogethes aeneus Fabricius, 1775) (Coleoptera: Nitidulidae) is the most important oilseed rape pest from the Brassicogethes genus and appears in oilseed rape fields after stem weevils when temperature exceeds $12^{\circ} \mathrm{C}$ (Láska and Kocourek, 1991; Alford et al., 2003; Williams, 2010). Direct damage caused by adult forms of stem weevils occurs as a result of the oviposition inside plant tissue. More significant damage occurs as a result of the larvae feeding inside leave petioles, secondary shoots and stems. In general, damages result in short and tiny plants. It is enough to find only one larva inside the plant to classify damage from the feeding of the larvae as significant. The plant deforms, stunts and decays rapidly. One day after oviposition plants begin to respond with histological changes, which are resulted by the slower development of the plant above the attacked part, the deformation of the stem and the cracking tissue at different places. Due to the destruction of the central part of the stem, a deformation of the tissue and loss of plant vigors, the number of siliques per plant is reduced. The plant produces lateral shoots and has a bushy appearance which causes a ripening maturity and makes difficulties to harvest. Feeding of adults and larvae of the pollen beetle cause bud abscission with podless stalks or siliques that can be distorted and weakened (Klukowski and Kelm, 2000; Alford et al., 2003; Krause et al., 2006; Williams, 2010). Yield losses up to 50\% caused by stem weevils and up to $70 \%$ by pollen beetle have been reported (Alford et al., 2003). 
The number of insecticides treatments for pest control in oilseed rape as well as the cost of treatment and insecticides in Europe have been changing over the last 30 years (Walczak and Mrówczyński, 2006). Continued frequent use of insecticides may decrease effectiveness of insecticides for stem weevils and pollen beetle control and is already present in most countries in the European Union (Heimbach et al., 2006; Thieme et al., 2010; Gotlin Čuljak et al., 2013). According to Maceljski (2002) both species of stem weevils and pollen beetle are sufficiently controlled with the single insecticide application, especially with earlier applications at the beginning of the stem elongation. In other EU countries the first treatment is performed against cabbage stem weevil and the second against rape stem weevil and pollen beetle as two insecticides application in spring significantly reduces the pollen beetle populations (Wahmhoff, 2000).

The aim of this research was to determine possibility of joint control of stem weevils and pollen beetle which might reduce insecticide input and result in slower resistance development of the oilseed rape pest.

\section{Materials and methods}

The experiment was conducted in Croatia during 2017 and 2018 at two locations, Koprivnički Bregi $\left(46^{\circ} 7^{\prime} 34.06^{\prime \prime} \mathrm{N} 16^{\circ} 53^{\prime} 42.55^{\prime \prime} \mathrm{E}\right)$ in Koprivnica-Križevci county and

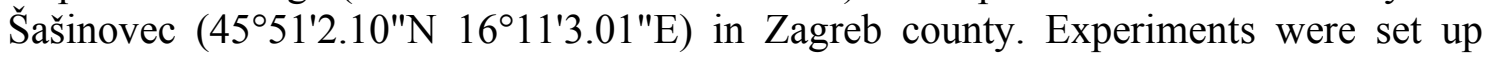
according to the EPPO guidelines (2014) for investigating the effectiveness of insecticides for the control of stem weevils (PP 1/219 (1)) and pollen beetles (PP 1/178 (2)). During both growing seasons, the experiment was set up according to a random block design in four replications with nine different treatments (Table 1). The size of each experimental plot was $30 \mathrm{~m}^{2}$ with average plant density in harvest of 39 plants $/ \mathrm{m}^{2}$ during both investigation years. Oilseed rape had been drilled on September 5 for both experimental years with cultivar PR46W14. Row space was $14 \mathrm{~cm}$ and previous crop was winter wheat. The crop was fertilized with $90 \mathrm{~kg} \mathrm{~N} / \mathrm{ha}$ in autumn and spring and with $40 \mathrm{~kg}$ S/ha in autumn. The experiment included commercial products, applied according to recommended and registered doses, with single active ingredient: lambda cyhalothrin ( $6.25 \mathrm{ml}$ of active ingredient/ha) and deltamethrin ( $5 \mathrm{~g}$ active ingredient/ha) as well as combined products thiacloprid (55 g of active ingredient/ha) + deltamethrin $(5 \mathrm{~g}$ active ingredient/ha) and chlorpyrifos-ethyl (450 ml active ingredient/ha) + cypermethrin (45 ml active ingredient/ha). Chlorpyrifos-ethyl belongs to organophosphates and is classified into group 1. Deltamethrin, lambda cyhalotrin and cypermethrin belong to pyrethroids and are classified into group 3. Both groups have contact action. Thiacloprid belongs to neonicotinoids and is classified into group 4 with systemic action (IRAC, 2019).

Table 1. Treatments and active ingredients during two years experiment

\begin{tabular}{c|c}
\hline treatment & active ingredient/pests \\
\hline 1 & lambda cyhalothrin/stem weevils \\
2 & thiacloprid + deltamethrin/stem weevils \\
3 & deltamethrin/pollen beetles \\
4 & chlorpyrifos-ethyl + cypermethrin/pollen beetles \\
5 & lambda cyhalothrin/stem weevils and deltamethrin/pollen beetles \\
6 & lambda cyhalothrin/stem weevils and chlorpyrifos-ethyl +cypermethrin/pollen beetles \\
7 & thiacloprid+deltamethrin/stem weevils and deltamethrin/pollen beetles \\
8 & thiacloprid+deltamethrin/stem weevils and chlorpyrifos-ethyl + cypermethrin/pollen beetles \\
9 & untreated control \\
\hline
\end{tabular}


Oilseed rape crop was treated using Solo Accu Power sprayer with constant pressure of 2 bar after the decision threshold of pest population was exceeded. Optimal treatment period was determined by monitoring the occurrence and population density of stem weevils using yellow water traps. The decision threshold for pollen beetle was determined by beating 50 terminal inflorescences per each treatment into trays when flower buds were but still closed with leaves (BBCH 50). The decision threshold for $C$. napi control was 10 adult forms and for the $C$. pallidactylus control 20 adult forms caught in a yellow water traps in three consecutive days (PP 1/219 (1)). The decision threshold for pollen beetle was 0.8 - 1 adults per terminal inflorescence in growth stage when the flower buds were still covered with leaves and barely noticeable (BBCH 50) (PP 1/178 (2)). The experiment was evaluated according to EPPO guidelines (PP 1/219 (1), PP 1/178 (2)) (2014) to investigate the effectiveness of insecticides. For stem weevils, the experiment was evaluated by dissecting 10 plants taken from each treatment during the flowering (BBCH 65 - 69). The number larvae and feeding tubes were recorded. The effectiveness of insecticides for the pollen beetle control was evaluated 24 hours and three days after the insecticides application. The number of live adult forms was recorded on 50 terminal inflorescences. Harvest of each experimental plot was performed by the trial combine and seed from each experimental plot was weighed and yield was converted to hectare based on 9\% seed moisture. A two-way ANOVA was performed to test the difference between treatments for the number larvae and feeding tubes caused by the larval feeding, the number of live adult forms of pollen beetle and yield. The averages are compared to Tukey's rank test. Data were statistically analysed by computer program "R" (Version 3.1.2., 2014).

\section{Results}

For the first year of experiment at Koprivnički Bregi location population dynamics of stem weevils adults, from yellow water traps, is present in Figure 1. Decision threshold for C. pallidactylus was reached on February 26 and on March 21, 24, 26 and 30. Decision threshold for $C$. napi was reached on March 30. Table 2 presents average number of pollen beetle adults recorded by beating into trays method. Decision threshold was reached on March 29 (BBCH 50).

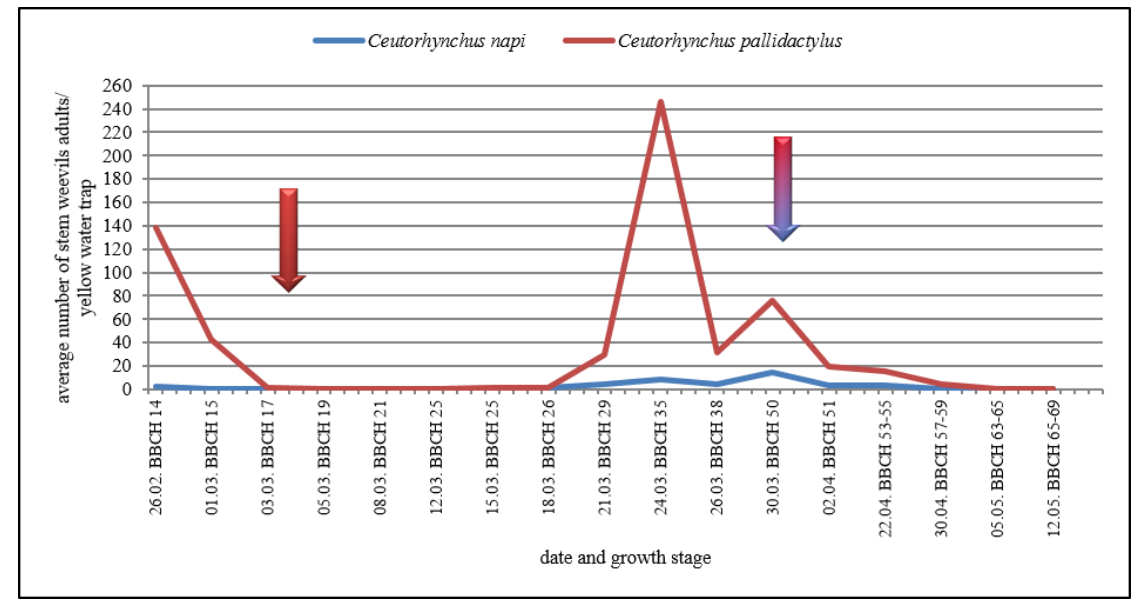

Figure 1. Average number of adult forms of C. pallidactylus and C. napi per yellow water trap at Koprivnički Bregi site (arrows present date of insecticide application) 
Table 2. Average number of the pollen beetle adults per plant at Koprivnicki Bregi site, $\mathrm{BBCH} 50$

\begin{tabular}{c|c|c|c|c}
\hline $\begin{array}{c}\text { replication } \\
\text { treatment }\end{array}$ & I & II & III & IV \\
\hline 1 & 0.9 & 1.2 & 1.4 & 0.9 \\
2 & 1 & 1.2 & 1.4 & 0.9 \\
3 & 0.8 & 1.2 & 1.1 & 0.9 \\
4 & 1.3 & 1.2 & 1.2 & 0.9 \\
5 & 1 & 1.1 & 1.3 & 1.3 \\
6 & 1.2 & 1.1 & 1.5 & 0.9 \\
7 & 0.9 & 1.2 & 1.3 & 0.9 \\
8 & 0.9 & 1.4 & 1.3 & 0.8 \\
9 & 1.9 & 0.8 & 1.5 & \\
\hline
\end{tabular}

First insecticides application was conducted on treatments 1, 2, 5, 6, 7, and 8 on March 2 after threshold for $C$. pallidactylus was exceeded. Second insecticide application was conducted on March 30 after thresholds for both species of stem weevils and pollen beetle were exceeded.

For the second year of experiment at Šašinovec location population dynamics of stem weevils adults, from yellow water traps, is present in Figure 2. Decision threshold for C. pallidactylus was reached on March 1 and 5. Decision threshold for C. napi was reached on March 26. The average number of pollen beetle adults recorded by beating into trays method are present in Table 3. Decision threshold was reached on March 30 (BBCH 50) at treatments 3, 4 and 9.

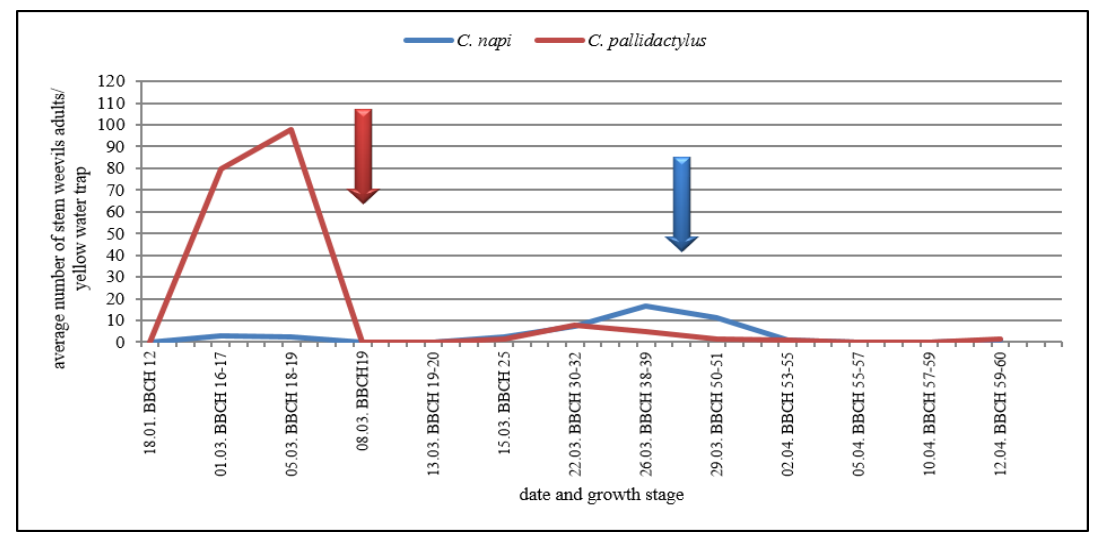

Figure 2. Average number of adult forms of C. pallidactylus and C. napi per yellow water trap at Šašinovec site (arrows present date of insecticide application)

Table 3. Average number of the pollen beetle adults per plant at Šašinovec, BBCH 50

\begin{tabular}{c|c|c|c|c}
\hline $\begin{array}{c}\text { replication } \\
\text { treatment }\end{array}$ & I & II & III & IV \\
\hline 1 & 0.06 & 0.1 & 0.1 & 0.08 \\
2 & 0.04 & 0.08 & 0.06 & 0.1 \\
3 & 0.8 & 0.8 & 0.8 & 0.8 \\
4 & 0.8 & 0.98 & 0.8 & 0.8 \\
5 & 0.08 & 0.42 & 0.04 & 0.1 \\
6 & 0.02 & 0.1 & 0.12 & 0.14 \\
7 & 0.04 & 0.04 & 0.1 & 0.08 \\
8 & 0.02 & 0.02 & 0.04 & 0.08 \\
9 & 0.9 & 0.82 & 0.8 & 0.9 \\
\hline
\end{tabular}


First insecticides application was conducted on treatments 1, 2, 5, 6, 7, and 8 on March 7 after threshold for $C$. pallidactylus was exceeded. Second insecticide application was conducted on March 27 after threshold for $C$. napi was exceeded. Third insecticide application was conducted on treatments 3 and 4 on March 30 after decision threshold for pollen beetle was exceeded.

Results of a two-way ANOVA conducted to test differences between treatments for stem weevil larvae for all locations and years are present in Figure 3. Statistical analysis showed a significant difference between years $(\mathrm{F}=504.8 ; \mathrm{DF}=1.8 ; \mathrm{P}<0.001)$ and between treatments $(\mathrm{F}=23.4 ; \mathrm{DF}=8.8 ; \mathrm{P}<0.0001)$. Tukey's HSD post hoc test showed significant differences between interaction of years and treatments.

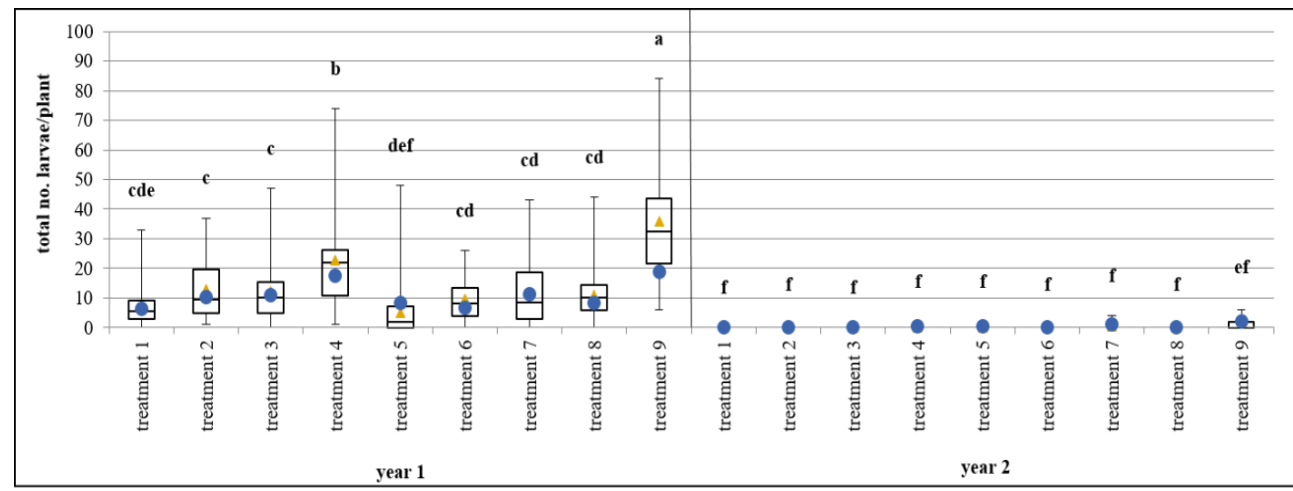

Figure 3. Two-way ANOVA for number of stem weevils larvae per plant (each treatment is presented by upper and lower quartile, minimum and maximum values; median is presented by middle line, middle value by triangle and standard deviation by circle; ranges not connected with the same latter are significantly different)

Results of a two-way ANOVA conducted to test differences between treatments for feeding tubes of stem weevils for all locations and years are present in Figure 4. Statistical analysis showed a significant difference between years $(\mathrm{F}=536.06 ; \mathrm{DF}=1.8 ; \mathrm{P}<0.0001)$ and between treatments $(\mathrm{F}=8.4 ; \mathrm{DF}=8.8 ; \mathrm{P}<0.0001)$ as well as interaction between treatments and years $(\mathrm{F}=4.7 ; \mathrm{DF}=8.8 ; \mathrm{P}<0.0001)$. Tukey's HSD post hoc test showed significant differences between interaction of years and treatments.

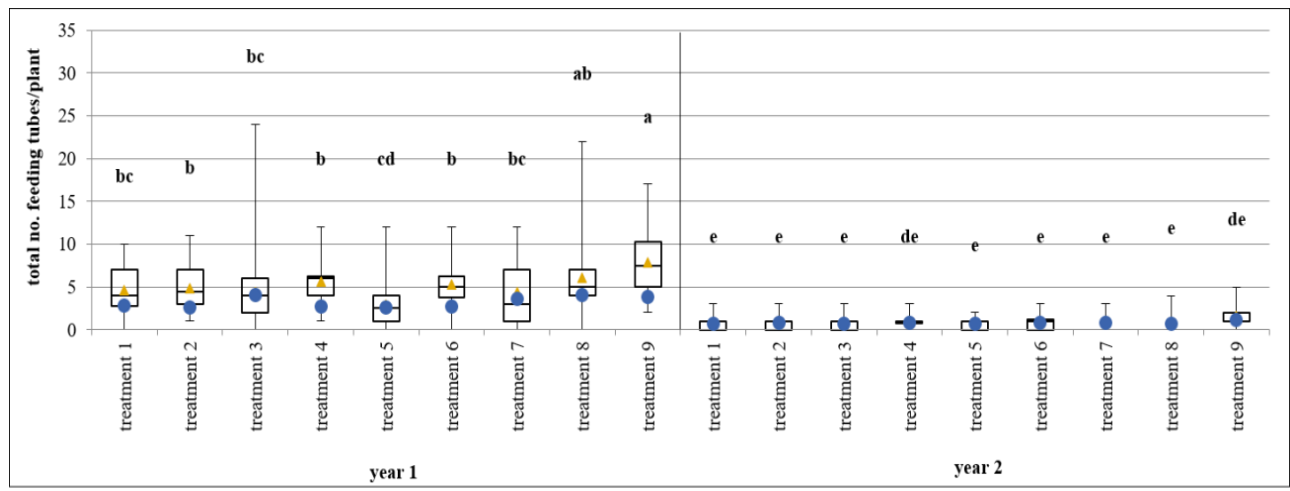

Figure 4. Two-way ANOVA for number of stem weevils feeding tubes per plant (each treatment is presented by upper and lower quartile, minimum and maximum values; median is presented by middle line, middle value by triangle and standard deviation by circle; ranges not connected with the same latter are significantly different) 
Results of a two-way ANOVA conducted to test differences between treatments for live adults of pollen beetle 24 hours after insecticides application for all locations and years are present in Figure 5. Statistical analysis showed a significant difference between years $(\mathrm{F}=86.06 ; \mathrm{DF}=1.8 ; \mathrm{P}<0.0001)$ and between treatments $(\mathrm{F}=54.8 ; \mathrm{DF}=8.8$; $\mathrm{P}<0.0001)$ as well as interaction between treatments and years $(\mathrm{F}=25.9 ; \mathrm{DF}=8.8$; $\mathrm{P}<0.0001)$. Tukey's HSD post hoc test showed significant differences between interaction of years and treatments.

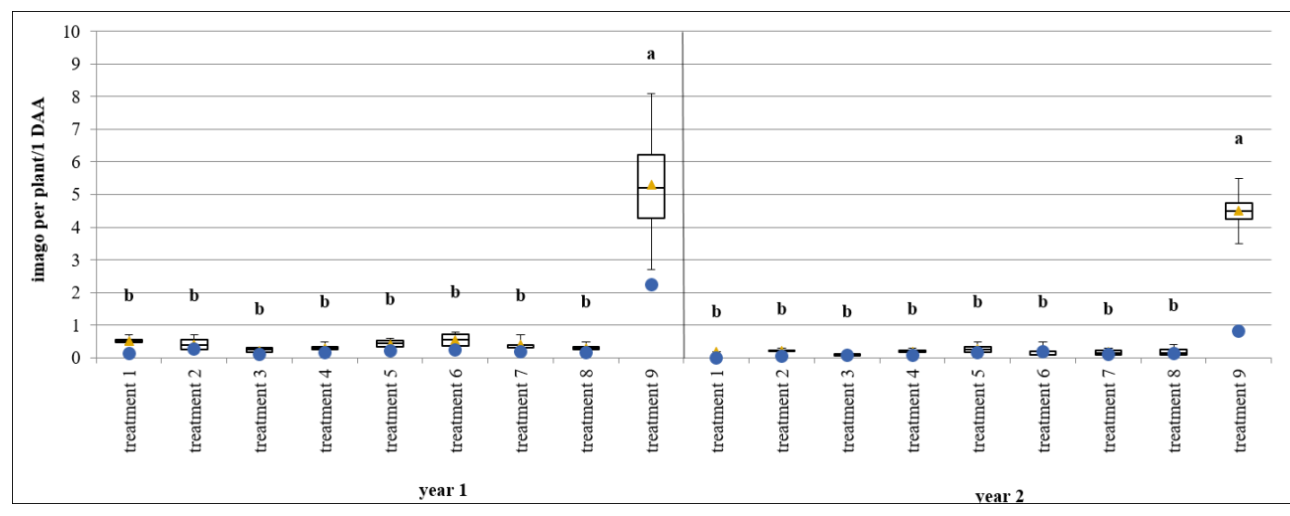

Figure 5. Two-way ANOVA for number of live pollen beetle adults 24 hours after application (each treatment is presented by upper and lower quartile, minimum and maximum values; median is presented by middle line, middle value by triangle and standard deviation by circle; ranges not connected with the same latter are significantly different)

Results of a two-way ANOVA conducted to test differences between treatments for live adults of pollen beetle 3 days after insecticides application for all locations and years are present in Figure 6. Statistical analysis showed a significant difference between years $(\mathrm{F}=89.5 ; \mathrm{DF}=1.8 ; \mathrm{P}<0.0001)$ and between treatments $(\mathrm{F}=44.1 ; \mathrm{DF}=8.8 ; \mathrm{P}<0.0001)$ as well as interaction between treatments and years $(\mathrm{F}=16.5 ; \mathrm{DF}=8.8 ; \mathrm{P}<0.0001)$. Tukey's HSD post hoc test showed significant differences between interaction of years and treatments.

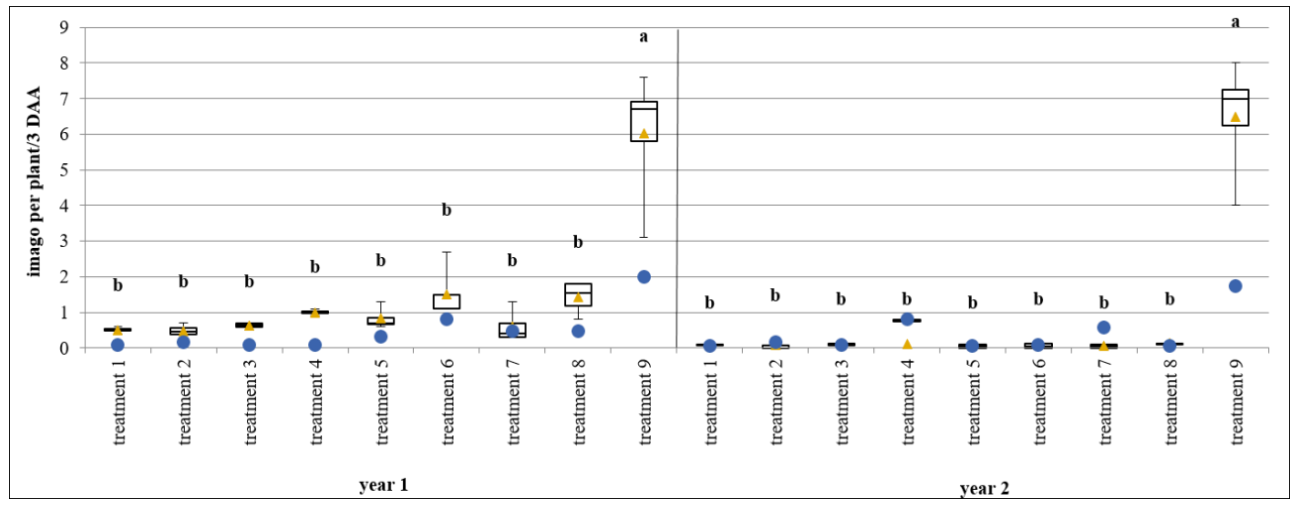

Figure 6. Two-way ANOVA for number of live pollen beetle adults 3 days after application (each treatment is presented by upper and lower quartile, minimum and maximum values; median is presented by middle line, middle value by triangle and standard deviation by circle; ranges not connected with the same latter are significantly different) 
Results of a two-way ANOVA conducted to test differences between treatments for yield of oilseed rape for all locations and years are present in Figure 7. Statistical analysis of data showed a significant difference between years $(\mathrm{F}=163.3 ; \mathrm{DF}=1.8 ; \mathrm{P}<0.0001)$. No statistically significant differences between treatments $(\mathrm{F}=1.5 ; \mathrm{DF}=8.8 ; \mathrm{P}<0.1922)$ and interaction between treatments and years $(\mathrm{F}=1.2 ; \mathrm{DF}=8.8 ; \mathrm{P}<0.3005)$ were recorded.

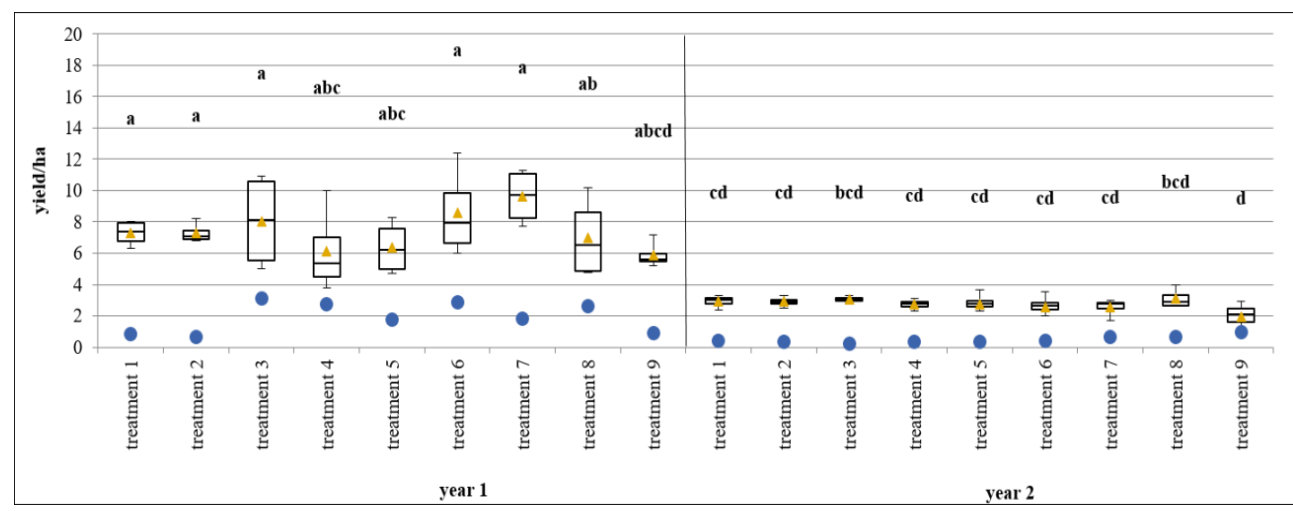

Figure 7. Two-way ANOVA for oilseed rape seed yield per hectare (each treatment is presented by upper and lower quartile, minimum and maximum values; median is presented by middle line, middle value by triangle and standard deviation by circle; ranges not connected with the same latter are significantly different)

\section{Discussion}

During both years of research, the first insecticide application was performed against adult forms of $C$. pallidactylus, which is coincided by the biology of this species. Another insecticide application was performed against $C$. napi and Brassicogethes sp. as both species reached the decision threshold at the same time.

The main indicator of the effectiveness of insecticides is the number of stem weevils larvae in plants and the yield of rapeseed (EPPO, 2014). The number of larvae and the number feeding tubes caused by the diet of stem weevil larvae in rapeseed plants, were significantly higher in the first experimental year compared with second year. The main reason is the later positioning of the yellow water traps in the crop of the first year and it is very likely that, by the time of the first application of the insecticide, the decision threshold for the control of $C$. pallidactylus had already been reached. As both sexes of C. pallidactylus tend to appear simultaneously (Juran et al., 2011) there is a possibility that copulation has occurred and that females have laid eggs before insecticide application, which is contrary to the results of Büchs (1998), who states that treatment of adult forms of $C$. pallidactylus may be delayed two weeks after the decision threshold is exceeded. Due to the large differences in the abundance of stem weevil larvae in plants in both years, it can be concluded that insecticides should be applied immediately after decision threshold for $C$. pallidactylus control is reached and not after two weeks when females become sexually mature as proposed by Kostal (1992), Büchs (1998) and Seidenglanz et al. (2009). The decision threshold should be considered as the number of females caught in yellow water traps, as suggested by Wahmhoff (2000). This is especially important when pests appear in high adult population and when the number of females exceeds the critical number of 10 for $C$. napi or 20 adult forms for 
C. pallidactylus per yellow water trap. Considering different temporal occurrence of adult stages of both stem weevil species, insecticides application at two deadlines during the spring could significantly reduce the population of adult forms (Wahmhoff, 2000). The highest efficacy in reducing larval abundance in rapeseed plants in the first year was observed with the use of a lambda cyhalothrin against adult forms (treatments 1 and 5). Systemic active ingredients should have good efficacy on larvae within plants (Tomlin, 1994) but on treatments where thiacloprid (treatments 2, 7 and 8) was used in combination with deltamethrin, the number of stem weevil larvae was not significantly reduced (Gratina et al., 2011). This may be due to lower temperatures at the first insecticide application against adult forms of $C$. pallidactylus (Seta and Wolski, 2006) at which neonicotinoids have lower efficacy (Tomlin, 1994). During second year, no significant differences were observed in the number of stem weevils larvae in rapeseed plants. Differences are not present even on treatments three and four where stem weevils were not controlled and as one reason may be the different distribution of these pests across the field (Green et al., 1991; Kuhne, 1997). Uneven distribution across the surface has also been recorded for adult forms of pollen beetle (Ferguson et al., 2003, 2005). At treatments where pollen beetle was controlled with the chlorpyrifos-ethyl and cypermethrin (treatment 4), satisfactory effects on stem weevil larvae inside the stem were not achieved during both years of the study, although the organophosphorus component penetrate deeper into plant tissue (Corteva, 2019) which is partially confirmed by Milovac et al. (2017). This is in contradiction with the results of Inđic et al. (2011), but the applied insecticide dose per hectare (11), in their investigation was twice higher than recommended. The same authors conclude that there are no statistically significant differences in the number of larvae in the plant between the treatment of adult forms of stem weevils with chlorpyrifos-ethyl + cypermethrin and deltamethrin.

The results of the ANOVA for the number of larvae are also accompanied by the number of the feeding tubes which is to be expected since the damage depends on their presence and their number in the plant. The differences in the number of feeding tubes between treatments 1 and 6 (lambda cyhalothrin was used in both treatments to control stem weevils) could be explained by the different spatial distribution of adults across the field. Thiacloprid did not have a satisfactory effect on the number of feeding tubes in the plant due to the lower efficacy at lower temperatures (mean daily temperature ranged from 3.4 to $6.7^{\circ} \mathrm{C}$ ) at the time of application of the insecticide (CMHS, 2019). During both years of the study, no statistically significant differences were found between treatments against adult forms of pollen beetle, although a year later, resistance to pyrethroids was confirmed in Croatia (Gotlin Čuljak et al., 2013).

Although no statistically differences were found between treatments for rapeseed yield in both years, it is important to observe the increase in yield from a biological importance, not a statistical significance level (Lovell, 2013). In all treatments where insecticides were applied, during the two years of the study, a relative increase in the yield of rapeseed ranged from 4 to $63 \%$ compared to the untreated control. Although the highest insecticide efficacy, for number of stem weevil larvae and feeding tubes was observed for the lambda-cyhalothrin (treatment 1 and 5 against stem weevils) did not ultimately affect the seed yield, as confirmed by Seta and Wolski (2006). The highest yield increasing in the first year of investigation was recorded on treatment 7 (63\% increase in yield) where stem weevils were controlled with combination of thiacloprid and deltamethrin, and pollen beetle with deltamethrin, which is in contrast with the results of the statistical analysis for the number of larvae. A significant uniformity of the rapeseed yield across all treatments 
was observed during second year, which again demonstrates that insecticide application against adults of $C$. pallidactylus is required immediately after decision threshold is exceeded. Any application of insecticides against stem weevils results in an increase in yield regardless results cannot be statistically significant, which is confirmed by Seta and Mrówczyński (1999), Seta and Wolski (2006), Petraitiené et al. (2012). The results show that stem weevils can reduce rapeseed seed yield by up to $60 \%$ and $37 \%$ on average, as confirmed by several authors (Walczak et al., 1997; Kelm and Walczak, 1998; Kelm and Klukowski, 2000; Seta and Mrówczyński, 2000; Alford et al., 2003; Dechert and Ulber, 2004).

\section{Conclusions}

Based on the results of the control and considering the life cycle of stem weevils, the first application of insecticide against adult forms of $C$. pallidactylus is critical point in protecting rapeseed against these pest. $C$. napi can be controled with pollen beetles as the decision thresholds for these two pests coincide. Considering the confirmed resistance of pollen beetle to pyrethroids and possible resistance to organophosphorus insecticides in joint control of $C$. napi and Brassicogethes sp. producers should pay attention of the proper selection of insecticides and insecticides rotation to achieve effective control. For the future research, it is highly recommended to investigate the impact of stem weevils on different components of oilseed rape yield and to determine which component has the most significant impact on yield lose.

\section{REFERENCES}

[1] Alford, D. V., Nilsson, C., Ulber, B. (2003): Insect pests of oilseed rape crops. - In: Alford, D. V. (ed.) Biocontrol of oilseed rape pests. Blackwell Publishing, London.

[2] Büchs, W. (1998): Strategies to control the cabbage stem weevil (Ceutorhynchus pallidactylus Mrsh.) and the oilseed rape stem weevil (Ceutorhynchus napi Gyll.) by a reduced input of insecticides. - IOBC Bulletin 21(5): 205-220.

[3] CMHS (2019): Croatian Meteorlogical and Hydrological Service. https://meteo.hr/index_en.php/.

[4] Corteva (2019): Corteva Agriscience. - https://www.chlorpyrifos.com/.

[5] Dechert, G., Ulber, B. (2004): Interactions between the stem-mining weevils Ceutorhynchus napi Gyll. and Ceutorhychus pallidactylus (Marsh.) (Coleoptera: Curculionidae) in oilseed rape. - Agricultural and forest entomology 6: 193-198.

[6] EPPO (2014): Guidelines for efficacy evaluation of plant protection product - insecticides $\&$ acaricides, Efficacy evaluation of insecticides - Ceutorhynchus napi and Ceutorhynchus pallidactylus on rape. - Bulletin OEPP/EPPO Bulletin 33: 65-69.

[7] Ferguson, A. W., Klukowski, Z., Walczak, B., Clark, S. J., Mugglestone, M. A., Perry, J. N., Williams, I. H. (2003): Spatial distribution of pest insects in oilseed rape: implications for integrated pest management. - Agriculture, ecosystems and environment 95: 509-521.

[8] Ferguson, A. W., Barari, H., Warner, D. J., Campbell, J. M., Smith, E. T., Watts, N. P., Williams, I. H. (2005): Distributions and interactions of the stem miners Psylliodes chrysocephala and Ceutorhynchus pallidactylus and their parasitoids in a crop of winter oilseed rape (Brassica napus). - Entomologia experimentalis et applicata 119: 81-92.

[9] Gotlin Čuljak, T., Jelovčan, S., Grubišić, D., Juran, I., Ilić Buljan, M. (2013): Pojava rezistentnosti repičinog sjajnika (Meligethes spp.) na piretroide u usjevima uljane repice (Brassica napus L.) u Hrvatskoj. - Glasilo biljne zaštite 5: 379-383. 
[10] Gratina, I., Apenite, I., Turka, I. (2011): Commonly found species of Ceutorhynchus (Coleoptera: Curculionidae) on the oilseed rape in Lativa. - Acta Biologica Daugavpils University 11(2): 260-264.

[11] Green, D. B., Bennison, J., Emmett, B., Walters, K. (1991): Evaluation of alphacypermethrin and phorate against cabbage stem weevil in autumn-sown oilseed rape. - Annals of Applied Biology 118: 4-5.

[12] Heimbach, U., Müller, A., Thieme, T. (2006): First steps to analyse pyrethroid resistance of different oil seed rape pests in Germany. - Nacrichten aus Deutschland Pflanzenschutzdienst 58: 1-5.

[13] Inđić, D., Vuković, S., Grahovac, M., Mrkajić, M., Gvozdenac, S., Šunjka, D., Tanaskovič, S., Stevanović, V. (2011): Validnost nekoliko parametara u oceni efekata insekticida u suzbijanju Ceutorhynchus spp. na uljanoj repici. - Biljni lekar 39: 481-489.

[14] IRAC (2019): Insecticide Resistance Action Committee. - https://www.irac-online.org/.

[15] Juran, I., Gotlin Čuljak, T., Grubišić, D. (2011): Rape Stem Weevil (Ceutorhynchus napi Gyll. 1837) and Cabbage Stem Weevil (Ceutorhynchus pallidactylus Marsh. 1802) (Coleoptera: Curculionidae) - Important Oilseed Rape Pests. - Agriculture Conspectus Scientificus 76(2): 93-100.

[16] Kelm, M., Walczak, B. (1998): The relationship between the stem weevil (Ceutorhynchus pallidactylus Marsh.) injury and losses of the flower buds. - IOBC/wprs Bulletin 21(5): 147-151.

[17] Kelm, M., Klukowski, Z. (2000): Weather as a factor determining damage caused by oilseed rape pests. - IOBC/wprs Bulletin 23(6): 119-124.

[18] Klukowski, Z., Kelm, M. (2000): Stenomalina gracilis (Walker), a new parasitoid reared from Ceutorhynchus napi Gyll. in Poland. - IOBC/wprs Bulletin 23(6): 135-138.

[19] Kostal, V. (1992): Monitoring of activity and abundance of adult pollen beetle (Meligethes aeneus $\mathrm{F}$.) and cabbage stem weevil (Cenutorhynchus pallidactylus Marsh.) in winter rape stand. - Oilseed crops 38(3-4): 297-306.

[20] Krause, U., Koopmann, B., Ulber, B. (2006): Impact of rape stem weevil, Ceutorhynchus napi, on the early stem infection of oilseed rape by Phoma lingam. - IOBC/wprs Bulletin 29(7): 323-328.

[21] Kuhne, W. (1997): Studies on the distribution of infestation by the weevils Ceutorhynchus napi Gyll., Ceutorhynchus quadridens Panz. and Ceutorhynchus assimilis Payk. in largescale plantings of winter rape. - Archiv für Phytopathologie und Pflanzenschutz 13(2): $109-115$

[22] Láska, P., Kocourek, F. (1991): Monitoring of flight activity in some crucifer-feeding pests by means of yellow water traps. - Acta Entomol Bohemos 88: 25-35.

[23] Lovell, D. P. (2013): Biological importance and statistical significance. - Journal of agricultural and food chemistry 61: 8340-8348.

[24] Maceljski, M. (2002): Poljoprivredna entomologija. - Zrinski, Čakovec.

[25] Milovac, Ž., Zorić, M., Franeta, F., Terzić, S., Petrović Obradović, O., Marjanović Jeromela, A. (2017): Analysis of oilseed rape stem weevil chemical control using a damage rating scale. - Pest Management Science 79(9): 1962-1971.

[26] Petraitiené, E., Brazauskiené, I., Vaitelyté, B. (2012): The effect of insecticides on pest control and productivity of winter and spring oilseed rape (Brassica napus L.). - In: Perveen, F. (ed.) Insecticides - Advances in Integrated Pest Management. InTech, New York.

[27] R Foundation for Statistical Computing (2014): R: A Language and Environment for Statistical Computing. - http://www.r-project.org/.

[28] Seidenglanz, M., Poslušná, J., Hrudová, E. (2009): The importance of monitoring the Ceutorhynchus pallidactylus female flight activity for the timing of insecticidal treatment. - Plant Protection Science 45(3): 103-112. 
[29] Seta, G., Mrówczyński, M. (1999): Harmfulness and possibility of cabbage stem weevil (Ceutorhynchus pallidactylus Marsh.) control in winter rape. - Progress in Plant Protection 39(2): 534-536.

[30] Seta, G., Wolski, A. (2006): Trial of qualification of harmfulness and effectiveness of Meligethes aeneus F. and Ceutorhynchus pallidactylus Marsh. on winter oilseed rape control in dependence of air temperature in spring time. - Progress in Plant Protection 46(2): 390-394.

[31] Thieme, T., Heimbach, U., Müller, A. (2010): Chemical control of insect pests and insecticide resistance in oilseed rape. - In: Williams, I. H. (ed.) Biocontrol-based integrated management of oilseed rape pests. Springer, Berlin.

[32] Tomlin, C. (1994): The Pesticide Manual, Incorporating The Agrochemicals Handbook. The British Crop Protection Council and The Royal Society of Chemistry, Bath.

[33] Wahmhoff, W. (2000): Integrieter Rapsanbau: Untersuchungen zur Entwicklung integrierter Produktionsverfahren am Beispiel des Winterrapses (Brassica napus L.). Erich Schmidt Verlag, Berlin.

[34] Walczak, B., Kelm, M., Karp, R., Smart, L. (1997): Use of semiochemicals in different types of traps for monitoring stem weevil (Ceutorhynchus sp.) flight to winter rape. Progress in plant protection 37(2): 25-27.

[35] Walczak, F., Mrówczyński, M. (2006): The endangerment of oilseed rape by pests in Poland. - IOBC/wprs Bulletin 29(7): 163.

[36] Williams, I. H. (2010): The major insect pests of oilseed rape in Europe and their management: an overview. - In: Williams, I. H. (ed.) Biocontrol-based integrated management of oilseed rape pests. Springer, Berlin. 